\title{
Phytotoxic steroidal saponins from Agave offoyana leaves
}

\author{
Andy J. Pérez ${ }^{\mathrm{a}, \mathrm{b}, *}$, Ana M. Simonet ${ }^{\mathrm{a}}$, Juan M. Calle ${ }^{\mathrm{a}}$, Łukasz Pecio ${ }^{\mathrm{b}}$, José O. Guerra ${ }^{\mathrm{c}}$, Anna Stochmal ${ }^{\mathrm{b}}$, \\ Francisco A. Macías ${ }^{a}$ \\ ${ }^{a}$ Grupo de Alelopatía, Departamento de Química Orgánica, Instituto de Biomoleculas (INBIO), Facultad de Ciencias, Universidad de Cádiz, C/República Saharaui s/n, Apdo. 40, \\ 11510-Puerto Real (Cádiz), Spain \\ ${ }^{\mathrm{b}}$ Department of Biochemistry, Institute of Soil Science and Plant Cultivation, State Research Institute, ul. Czartoryskich 8, 24-100 Puławy, Poland

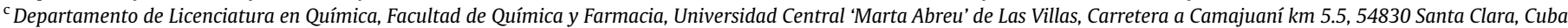

\section{A R T I C L E I N F O}

\section{Article history:}

Received 30 January 2014

Received in revised form 16 May 2014

Available online 14 June 2014

\section{Keywords:}

Agave offoyana

Spirostane saponin

Furostane saponin

Structural elucidation

Phytotoxic activity

Structure-activity relationship

\begin{abstract}
A B S T R A C T
A bioassay-guided fractionation of Agave offoyana leaves led to the isolation of five steroidal saponins (1-5) along with six known saponins (6-11). The compounds were identified as (25R)-spirost-5en-2 $\alpha, 3 \beta$-diol-12-one 3-O-\{ $\alpha$-L-rhamnopyranosyl-( $1 \rightarrow 3)-O$ - $\beta$-D-glucopyranosyl- $(1 \rightarrow 2)-O$ - $[\beta$-D-xylopyranosyl-( $1 \rightarrow 3)]$-O- $\beta$-D-glucopyranosyl-( $1 \rightarrow 4)-O$ - $\beta$-D-galactopyranoside $\}(\mathbf{1}),(25 R)$-spirost-5-en-3 $\beta$-ol-12-one

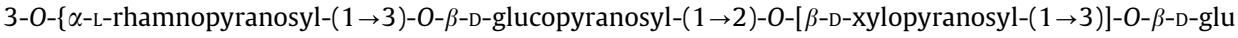
copyranosyl-( $1 \rightarrow 4)$-O- $\beta$-D-galactopyranoside $\}$ (2), (25R)-spirost-5-en-3 $\beta$-ol-12-one 3-O- $\{\beta$-D-xylopyrano syl-( $1 \rightarrow 3)-O-\beta$-D-glucopyranosyl- $(1 \rightarrow 2)-O$-[ $\beta$-D-xylopyranosyl-( $1 \rightarrow 3)]-O$ - $\beta$-D-glucopyranosyl- $(1 \rightarrow 4)-O-\beta$ -D-galactopyranoside $\quad$ (3), (25R)-26-O- $\beta$-D-glucopyranosylfurost-5-en-3 $\beta, 22 \alpha, 26$-triol-12-one 3-O$\{\alpha$-L-rhamnopyranosyl-( $1 \rightarrow 3)-O$ - $\beta$-D-glucopyranosyl- $(1 \rightarrow 2)-O-[\beta$-D-xylopyranosyl- $(1 \rightarrow 3)]-O$ - $\beta$-D-glucopyrano syl-( $1 \rightarrow 4)-O$ - $\beta$-D-galactopyranoside $(4)$ and (25R)-26-O- $\beta$-D-glucopyranosylfurost-5-en-3 $\beta, 22 \alpha, 26$-triol12-one 3-O-\{ $\beta$-D-xylopyranosyl- $(1 \rightarrow 3)-O$ - $\beta$-D-glucopyranosyl- $(1 \rightarrow 2)-O$-[ $\beta$-D-xylopyranosyl- $(1 \rightarrow 3)]-O-\beta$ D-glucopyranosyl-( $1 \rightarrow 4)-O-\beta$-D-galactopyranoside $\}$ (5) by comprehensive spectroscopic analysis, including one- and two-dimensional NMR techniques, mass spectrometry and chemical methods. The phytotoxicity of the isolated compounds on the standard target species Lactuca sativa was evaluated.
\end{abstract}

(c) 2014 Elsevier Ltd. All rights reserved.

\section{Introduction}

As part of our ongoing search for phytotoxic natural products, the results of further studies into Agave offoyana (Agavaceae) are presented here. The bioassay-guided isolation of phytotoxins from A. offoyana flowers was reported in our previous article, in which eleven steroidal saponins, including five new examples (Magueyosides A-E), were described (Pérez et al., 2013). The phytotoxicity results for the isolated compounds against lettuce (Lactuca sativa L.) were promising.

Despite the positive results obtained in the aforementioned studies and the fact that the saponins content in the flowers was $3.1 \%$ of dry weight, the availability of flowers from $A$. offoyana as a raw material for phytotoxins is limited. In the genus Agave the flowering stage takes place after several years of growth (6-8 years). The flowering stage happens only once in the lifetime of the plants

\footnotetext{
* Corresponding author at: Department of Biochemistry, Institute of Soil Science and Plant Cultivation, State Research Institute, ul. Czartoryskich 8, 24-100 Puławy, Poland. Tel.: +48 8188 63421x206; fax: +48 8188 63421x295.

E-mail address: aperez@iung.pulawy.pl (A.J. Pérez).
}

and they subsequently die (Bousios et al., 2007). The aim of the current investigation was to isolate the phytotoxic constituents from $A$. offoyana leaves ( $1.9 \%$ of dry weight) in a similar bioassay-guided procedure and to carry out a complete structural characterization of the isolated compounds.

\section{Results and discussion}

\subsection{Characterization of compounds}

Dried leaves of $A$. offoyana were extracted exhaustively with $\mathrm{EtOH} / \mathrm{H}_{2} \mathrm{O}$ (7:3). The extract was partitioned in $n$-BuOH/water and the organic phase was subjected to a bioassay-guided fractionation by VLC on RP-18 to give seven fractions. Eleven steroidal saponins 1-11 (Fig. 1) were obtained after multiple separation procedures on the active fractions (see Section 2.2). Six of these compounds were previously reported as Agabrittonoside E (6) (Macías et al., 2010), Magueyosides A (7) and B (8) (Pérez et al., 2013), Agabrittonosides D (9) and A (10) (Macías et al., 2007) and Cantalasaponin-1 (11) (Sati and Pant, 1985). The structures 

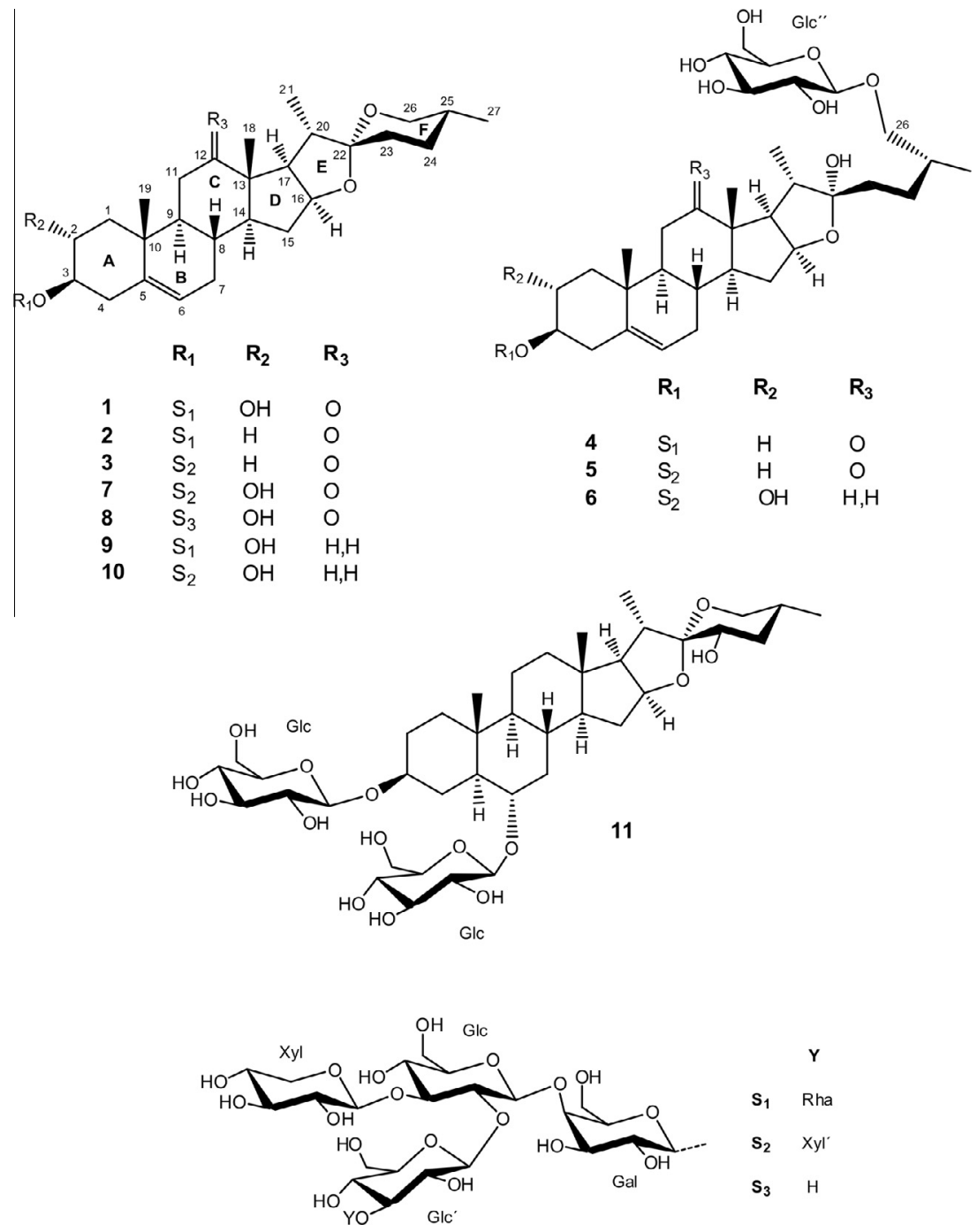

Fig. 1. Chemical structures of saponins 1-11, isolated from A. offoyana leaves.

of the compounds were elucidated on the basis of spectroscopic data obtained by ${ }^{1} \mathrm{H},{ }^{13} \mathrm{C}, 2 \mathrm{D}$ (HSQC, HMBC, DQF-COSY, TOCSY, ROESY, HSQC-TOCSY), 1D-ROESY (250 ms) and 1D-TOCSY (30, 60, $120 \mathrm{~ms}$ ) NMR experiments, HRESIMS, ESI-MS/MS and acid hydrolysis. Compounds $\mathbf{6}$ and $\mathbf{9}$ were previously characterized as a mixture from Agave brittoniana leaves. In the work described here these compounds were isolated in pure form and their HRESI-TOFMS spectra, absolute configuration of sugars and optical rotations were determined.

Compound 1 was obtained as a white amorphous solid and its molecular formula was assigned as $\mathrm{C}_{56} \mathrm{H}_{88} \mathrm{O}_{28}$ based on data from HRESI-TOFMS (positive ion mode; $m / z 1231.5345[\mathrm{M}+\mathrm{Na}]^{+}$, calcd. 1231.5360). ${ }^{1} \mathrm{H}$ and ${ }^{13} \mathrm{C}$ NMR assignments for the aglycone moiety of 1 (Table 1 ) were in good agreement with those of the aglycone moiety of $\mathbf{7}$ (Pérez et al., 2013), which suggested that Kammogenin (Marker et al., 1943) was the aglycone of $\mathbf{1}$. However, significant differences between compounds $\mathbf{1}$ and $\mathbf{7}$ were observed concerning the sugar portion. The ${ }^{1} \mathrm{H}$ NMR spectrum of 1 showed five anomeric signals at $\delta 4.92,5.14,5.24,5.51$ and 6.12 (Table 2) and these showed correlations in the HSQC spectrum with carbons at $\delta$ 103.7, 105.3, 104.6, 104.6 and 103.1, respectively. This result indicated a glycosidic chain of five sugar units. Individual sugar units were identified by a combination of ${ }^{1} \mathrm{H}-{ }^{1} \mathrm{H}$ COSY, 1D-TOCSY and 1D-ROESY experiments. The latter two spectra were acquired from the selective excitation of each anomeric proton. In this way, signals at $\delta 5.24$ and $\delta 5.51$ revealed typical spin systems of $\beta$-glucopyranosyl units (Glc and $\mathrm{Glc}^{\prime}$ ) and the signal at $\delta 5.14$ was assigned to a $\beta$-xylopyranosyl unit (Xyl). Likewise, a typical spin system for a $\beta$-galactopyranosyl unit was detected for the anomeric signal at $\delta 4.92$, which was confirmed by correlations with $\mathrm{H}-5_{\mathrm{Gal}}$ $\left(\delta 4.02\right.$, dd, $J=7.7,6.4 \mathrm{~Hz}$ ) and $\mathrm{H}-3_{\mathrm{Gal}}(\delta 4.14, \mathrm{~m})$ in the 1D ROESY experiment. The 1D TOCSY (120 ms) experiment on the anomeric signal at $\delta 6.12$ showed that magnetization was not properly transferred beyond $\mathrm{H}-2_{\mathrm{Rha}}(\delta 4.68$, dd, $J=1.7,3.5 \mathrm{~Hz})$. This finding, together with the presence of a methyl doublet at $\delta 1.64$ $(J=6.2 \mathrm{~Hz})$, is characteristic of a rhamnopyranosyl unit. A further selective TOCSY experiment on this methyl doublet ( $H-6_{\text {Rha }}$ ) allowed a sequential assignment of the signals from $\mathrm{H}-\mathrm{6}_{\mathrm{Rha}}$ to $\mathrm{H}-2_{\mathrm{Rha}}$ and the presence of a rhamnopyranosyl unit was confirmed. The correlations observed in the 1D ROESY experiment between $\mathrm{H}-1_{\text {Rha }}$ and $\mathrm{H}-2_{\text {Rha }}$, and the absence of a cross peak with $\mathrm{H}-3_{\text {Rha }}$ and $\mathrm{H}-5_{\mathrm{Rha}}$ suggested the $\alpha$-anomer. Finally, the ${ }^{13} \mathrm{C}$ signal assignments for each sugar unit were made through an exhaustive analysis of the correlations in HSQC and HSQC-TOCSY experiments.

The sequence of sugars chain and the connection with the aglycone were established by means of interglycosidic HMBC/ROESY correlations, which were observed between $\mathrm{H}-1_{\mathrm{Rha}}(\delta 6.12)$ and $\mathrm{C}-3_{\mathrm{Glc}^{\prime}}(\delta 83.9) / \mathrm{H}-3_{\mathrm{Glc}^{\prime}}(\delta 4.23), \mathrm{H}-1_{\mathrm{Glc}^{\prime}}(\delta 5.51)$ and $\mathrm{C}-2_{\mathrm{Glc}}(\delta 81.1) /$ $\mathrm{H}-2_{\mathrm{Glc}}(\delta 4.27), \mathrm{H}-1_{\mathrm{Xyl}}(\delta 5.14)$ and $\mathrm{C}-3_{\mathrm{Glc}}(\delta 87.6) / \mathrm{H}-3_{\mathrm{Glc}}(\delta 4.07)$, $\mathrm{H}-1_{\mathrm{Glc}}(\delta 5.24)$ and $\mathrm{C}-4_{\mathrm{Gal}}(\delta 79.2) / \mathrm{H}-4_{\mathrm{Gal}}(\delta 4.60), \mathrm{H}-1_{\mathrm{Gal}}(\delta 4.92)$ 
Table 1

${ }^{13} \mathrm{C}$ and ${ }^{1} \mathrm{H}$ NMR data $\left(\mathrm{I}\right.$ in $\mathrm{Hz}$ ) of the aglycone moieties of compounds $\mathbf{1 - 5}$ (pyridine- $\mathrm{d}_{5}, 500 \mathrm{MHz}$ ).

\begin{tabular}{|c|c|c|c|c|c|c|c|c|c|c|}
\hline & \multicolumn{2}{|c|}{ Magueyoside F (1) } & \multicolumn{2}{|c|}{ Magueyoside G (2) } & \multicolumn{2}{|c|}{ Magueyoside H (3) } & \multicolumn{2}{|c|}{ Magueyoside I (4) } & \multicolumn{2}{|c|}{ Magueyoside J (5) } \\
\hline & $\delta_{\mathrm{C}}$ & $\delta_{\mathrm{H}}$ & $\delta_{\mathrm{C}}$ & $\delta_{\mathrm{H}}$ & $\delta_{\mathrm{C}}$ & $\delta_{\mathrm{H}}$ & $\delta_{\mathrm{C}}$ & $\delta_{\mathrm{H}}$ & $\delta_{\mathrm{C}}$ & $\delta_{\mathrm{H}}$ \\
\hline $1_{\mathrm{ax}}$ & 45.6 & $1.26 \mathrm{dd}(12.5,11.4)$ & 37.3 & $0.88 \mathrm{ddd}(13.8,13.7,4.1)$ & 37.3 & $0.87 \mathrm{ddd}(13.7,13.7,4.1)$ & 37.3 & $0.88 \mathrm{ddd}(13.1,12.9,3.3)$ & 37.3 & 0.87 ddd $(13.3,13.2,3.4)$ \\
\hline $1_{\text {eq }}$ & & $2.20 \mathrm{dd}(12.5,4.5)$ & & 1.49 ddd $(13.8,3.5,3.5)$ & & 1.47 ddd $(13.7,3.6,3.6)$ & & $1.49^{\mathrm{b}}$ & & 1.47 ddd $(13.3,4.1,4.1)$ \\
\hline $2_{\mathrm{ax}}$ & 70.1 & $4.06 \mathrm{ddd}(11.4,8.8,4.5)$ & 30.2 & $1.67^{\mathrm{b}}$ & 30.2 & $1.65^{\mathrm{b}}$ & 30.2 & $1.68^{\mathrm{b}}$ & 30.2 & $1.66^{\mathrm{b}}$ \\
\hline $2_{\mathrm{eq}}$ & & & & $2.08^{\mathrm{b}}$ & & $2.06^{\mathrm{b}}$ & & $2.08^{\mathrm{b}}$ & & $2.06^{\mathrm{b}}$ \\
\hline 3 & 84.5 & $3.82 \operatorname{ddd}(11.5,8.8,5.1)$ & 78.3 & $3.84 \operatorname{dddd}(11.4,11.4,4.3,4.3)$ & 78.3 & 3.84 dddd $(11.4,11.4,4.7,4.7)$ & 78.3 & $3.84 \mathrm{dddd}(11.2,11.2,4.3,4.3)$ & 78.3 & $3.83 \mathrm{dddd}(11.4,11.4,4.2,4.2)$ \\
\hline $4_{\mathrm{ax}}$ & 37.9 & $2.56^{\mathrm{b}}$ & 39.4 & $2.41 \mathrm{~m}$ & 39.4 & $2.39 \mathrm{~m}$ & 39.4 & $2.41 \mathrm{~m}$ & 39.4 & $2.39 \mathrm{~m}$ \\
\hline $4_{\text {eq }}$ & & $2.75 \mathrm{dd}(13.9,5.1)$ & & 2.68 ddd $(13.4,4.3,2.2)$ & & 2.68 ddd $(13.5,4.7,2.2)$ & & $2.67 \mathrm{ddd}(13.3,4.3,2.0)$ & & 2.68 ddd $(13.5,4.2,2.1)$ \\
\hline 5 & 140.3 & - & 141.2 & - & 141.2 & - & 141.2 & - & 141.2 & - \\
\hline 6 & 122.1 & $5.29 \mathrm{~m}$ & 121.8 & $5.28 \mathrm{~m}$ & 121.8 & $5.27 \mathrm{~m}$ & 121.8 & $5.27 \mathrm{~m}$ & 121.8 & $5.26 \mathrm{~m}$ \\
\hline $7_{\mathrm{ax}}$ & 32.1 & $1.46^{\mathrm{b}}$ & 32.1 & $1.47^{\mathrm{b}}$ & 32.1 & $1.46^{\mathrm{b}}$ & 32.1 & $1.46^{\mathrm{b}}$ & 32.1 & $1.45^{\mathrm{b}}$ \\
\hline $7_{\mathrm{eq}}$ & & $1.86^{\mathrm{b}}$ & & $1.87^{\mathrm{b}}$ & & $1.86^{\mathrm{b}}$ & & $1.87^{\mathrm{b}}$ & & $1.86^{\mathrm{b}}$ \\
\hline 8 & 30.7 & $1.84^{\mathrm{b}}$ & 31.2 & 1.84 dddd $(11.2,11.2,10.9,5.2)$ & 31.2 & 1.83 dddd $(11.0,11.0,10.9,5.1)$ & 31.2 & $1.84^{\mathrm{b}}$ & 31.2 & $1.84^{\mathrm{b}}$ \\
\hline 9 & 52.4 & $1.41 \mathrm{ddd}(11.8,12.5,5.7)$ & 52.6 & 1.31 ddd $(11.2,13.1,5.8)$ & 52.6 & 1.30 ddd $(11.0,12.7,5.8)$ & 52.7 & 1.31 ddd $(11.9,13.1,5.6)$ & 52.7 & 1.30 ddd $(12.2,12.9,5.7)$ \\
\hline 10 & 38.8 & - & 37.9 & - & 37.9 & - & 37.9 & - & 37.9 & - \\
\hline $11_{\mathrm{ax}}$ & 37.9 & $2.56 \mathrm{dd}(14.9,12.5)$ & 37.9 & $2.53 \mathrm{dd}(14.6,13.1)$ & 37.9 & $2.52 \mathrm{dd}(14.8,12.7)$ & 37.9 & $2.55 \mathrm{dd}(14.5,13.1)$ & 37.9 & $2.54 \mathrm{dd}(14.6,12.9)$ \\
\hline $11_{\mathrm{eq}}$ & & $2.42 \mathrm{dd}(14.9,5.7)$ & & $2.30 \mathrm{dd}(14.6,5.8)$ & & $2.29 \mathrm{dd}(14.8,5.8)$ & & $2.31 \mathrm{dd}(14.5,5.6)$ & & $2.30 \mathrm{dd}(14.6,5.7)$ \\
\hline 12 & 212.8 & - & 213.0 & - & 213.0 & - & 213.2 & - & 213.2 & - \\
\hline 13 & 55.3 & - & 55.3 & - & 55.3 & - & 55.7 & - & 55.7 & - \\
\hline 14 & 56.1 & $1.43 \mathrm{ddd}(13.8,10.9,5.5)$ & 56.3 & $1.43 \mathrm{ddd}(13.6,11.2,5.1)$ & 56.3 & $1.43 \mathrm{ddd}(13.4,10.9,5.3)$ & 56.3 & $1.43 \mathrm{ddd}(12.9,11.9,5.4)$ & 56.3 & $1.43 \mathrm{ddd}(13.6,10.8,5.3)$ \\
\hline $15_{\mathrm{ax}}$ & 31.9 & $1.61 \mathrm{ddd}(13.8,12.3,6.6)$ & 31.9 & 1.61 ddd $(13.6,12.0,6.5)$ & 31.9 & 1.62 ddd $(13.4,12.0,6.6)$ & 32.2 & $1.63 \mathrm{ddd}(12.9,12.8,6.4)$ & 32.2 & 1.63 ddd $(13.6,12.1,6.5)$ \\
\hline $15_{\text {eq }}$ & & $2.11 \mathrm{ddd}(12.3,7.1,5.2)$ & & $2.11 \mathrm{ddd}(12.0,7.2,5.1)$ & & 2.10 ddd $(12.0,7.1,5.3)$ & & 2.09 ddd $(12.8,6.8,5.4)$ & & 2.08 ddd $(12.1,7.2,5.3)$ \\
\hline 16 & 80.1 & 4.49 ddd $(8.6,7.1,6.6)$ & 80.1 & 4.49 ddd $(8.6,7.2,6.5)$ & 80.1 & 4.49 ddd $(8.6,7.1,6.6)$ & 80.1 & $4.88 \mathrm{ddd}(8.5,6.8,6.4)$ & 80.1 & $4.88 \mathrm{ddd}(8.5,7.2,6.5)$ \\
\hline 17 & 54.4 & $2.81 \mathrm{dd}(8.6,6.8)$ & 54.4 & $2.81 \mathrm{dd}(8.6,6.9)$ & 54.4 & $2.81 \mathrm{dd}(8.6,6.8)$ & 55.2 & $2.96 \mathrm{dd}(8.5,6.8)$ & 55.2 & $2.95 \mathrm{dd}(8.5,6.8)$ \\
\hline 18 & 16.3 & $1.10 \mathrm{~s}$ & 16.3 & $1.10 \mathrm{~s}$ & 16.2 & $1.10 \mathrm{~s}$ & 16.4 & $1.16 \mathrm{~s}$ & 16.4 & $1.16 \mathrm{~s}$ \\
\hline 19 & 20.3 & $1.01 \mathrm{~s}$ & 19.2 & $0.93 \mathrm{~s}$ & 19.1 & $0.91 \mathrm{~s}$ & 19.2 & $0.94 \mathrm{~s}$ & 19.1 & $0.91 \mathrm{~s}$ \\
\hline 20 & 43.0 & $1.92 \mathrm{dq}(6.8,6.9)$ & 43.0 & $1.93 \mathrm{dq}(6.9,6.9)$ & 43.0 & $1.92 \mathrm{dq}(6.9,6.8)$ & 41.6 & $2.22 \mathrm{dq}(6.8,6.8)$ & 41.7 & $2.22 \mathrm{dq}(6.8,6.8)$ \\
\hline 21 & 14.3 & $1.35 \mathrm{~d}(6.9)$ & 14.3 & $1.36 \mathrm{~d}(6.9)$ & 14.3 & $1.35 \mathrm{~d}(6.9)$ & 15.6 & $1.56 \mathrm{~d}(6.8)$ & 15.6 & $1.56 \mathrm{~d}(6.8)$ \\
\hline 22 & 109.7 & - & 109.7 & - & 109.7 & - & 111.2 & - & 111.2 & - \\
\hline $23_{\mathrm{ax}}$ & 32.2 & $1.63^{\mathrm{b}}$ & 32.2 & $1.64^{\mathrm{b}}$ & 32.2 & $1.63^{\mathrm{b}}$ & 37.5 & $2.05^{\mathrm{b}}(2 \mathrm{H})$ & 37.5 & $2.05^{\mathrm{b}}(2 \mathrm{H})$ \\
\hline $23_{\text {eq }}$ & & $1.71^{\mathrm{b}}$ & & $1.70^{\mathrm{b}}$ & & $1.70^{\mathrm{b}}$ & & & & \\
\hline 24 & 29.6 & $1.57^{b}(2 \mathrm{H})$ & 29.6 & $1.57^{\mathrm{b}}(2 \mathrm{H})$ & 29.6 & $1.57^{\mathrm{b}}(2 \mathrm{H})$ & 28.7 & $1.68^{\mathrm{b}} ; 2.05 \mathrm{o}$ & 28.7 & $1.68^{\mathrm{b}} ; 2.04 \mathrm{o}$ \\
\hline 25 & 30.9 & $1.58^{\mathrm{b}}$ & 30.9 & $1.58^{\mathrm{b}}$ & 30.9 & $1.58^{\mathrm{b}}$ & 34.6 & $1.94 \mathrm{~m}$ & 34.6 & $1.94 \mathrm{~m}$ \\
\hline $26_{\mathrm{ax}}$ & 67.3 & $3.49 \mathrm{dd}(10.8,10.8)$ & 67.3 & $3.49 \mathrm{dd}(10.5 .10 .5)$ & 67.3 & $3.49 \mathrm{dd}(10.7,10.7)$ & 75.6 & $3.62 \mathrm{dd}(9.4,6.2) ; 3.96 \mathrm{dd}(9.4,7.2)$ & 75.7 & $3.62 \mathrm{dd}(9.4,6.3) ; 3.96 \mathrm{dd}(9.4,7.2)$ \\
\hline $26_{\text {eq }}$ & & $3.59 \mathrm{dd}(10.8,3.6)$ & & $3.59 \mathrm{dd}(10.5,3.6)$ & & $3.59 \mathrm{dd}(10.7,3.7)$ & & & & \\
\hline 27 & 17.7 & $0.70 \mathrm{~d}(5.8)$ & 17.7 & $0.70 \mathrm{~d}(5.8)$ & 17.7 & $0.70 \mathrm{~d}(5.8)$ & 17.8 & $0.99 \mathrm{~d}(6.7)$ & 17.8 & $0.99 \mathrm{~d}(6.7)$ \\
\hline
\end{tabular}

a Assignments were confirmed by DQF-COSY, 2D-TOCSY, HSQC, HSQC-TOCSY and HMBC experiments.

Overlapped. 
Table 2

${ }^{13} \mathrm{C}$ and ${ }^{1} \mathrm{H}$ NMR data $\left(J\right.$ in $\mathrm{Hz}$ ) of the sugar portions of compounds $\mathbf{1 - 5}$ (pyridine- $\left.\mathrm{d}_{5}, 500 \mathrm{MHz}\right){ }^{\mathrm{a}}$

\begin{tabular}{|c|c|c|c|c|c|c|c|c|c|c|}
\hline \multicolumn{3}{|c|}{ Magueyoside F (1) } & \multicolumn{2}{|c|}{ Magueyoside G (2) } & \multicolumn{2}{|c|}{ Magueyoside H (3) } & \multicolumn{2}{|c|}{ Magueyoside I (4) } & \multicolumn{2}{|c|}{ Magueyoside J (5) } \\
\hline & & $\beta$-D-Gal & & $\beta$-D-Gal & & $\beta$-D-Gal & & $\beta$-D-Gal & & $\beta$-D-Gal \\
\hline 1 & 103.7 & $4.92 \mathrm{~d}(7.5)$ & 103.2 & $4.86 \mathrm{~d}(7.6)$ & 103.2 & $4.87 \mathrm{~d}(7.7)$ & 103.2 & $4.86 \mathrm{~d}(7.7)$ & 103.2 & $4.88 \mathrm{~d}(7.9)$ \\
\hline 2 & 73.0 & $4.52 \mathrm{dd}(7.9,9.7)$ & 73.5 & $4.43 \mathrm{dd}(7.6,9.6)$ & 73.5 & $4.40 \mathrm{dd}(7.7,9.7)$ & 73.5 & $4.43 \mathrm{dd}(7.7,9.7)$ & 73.5 & $4.40 \mathrm{dd}(7.9,9.4)$ \\
\hline 3 & 75.9 & $4.14 \mathrm{~m}$ & 75.9 & $4.11 \mathrm{~m}$ & 75.8 & $4.11 \mathrm{dd}(9.7,3.1)$ & 75.9 & $4.11 \mathrm{dd}(9.7,3.5)$ & 75.8 & $4.12 \mathrm{dd}(9.4,3.7)$ \\
\hline 4 & 79.2 & $4.60 \mathrm{~d}(2.5)$ & 80.0 & $4.59 \mathrm{~d}(2.8)$ & 80.0 & $4.60 \mathrm{~d}(3.1)$ & 80.0 & $4.59 \mathrm{brs}$ & 80.0 & $4.60 \mathrm{brs}$ \\
\hline 5 & 76.1 & $4.02 \mathrm{dd}(7.7,6.4)$ & 75.7 & $3.97 \mathrm{dd}(8.6,5.5)$ & 75.7 & $3.97 \mathrm{dd}(8.5,5.7)$ & 75.7 & $3.97 \mathrm{dd}(8.8,5.4)$ & 75.6 & $3.98 \mathrm{dd}(8.9,5.4)$ \\
\hline \multirow[t]{3}{*}{6} & 61.1 & $4.18 \mathrm{dd}(10.5,6.4)$ & 61.0 & $4.18 \mathrm{dd}(10.6,5.5)$ & 61.0 & $4.18 \mathrm{dd}(10.5,5.7)$ & 61.0 & $4.18 \mathrm{dd}(10.6,5.4)$ & 61.0 & $4.18 \mathrm{dd}(10.0,5.4)$ \\
\hline & & $4.57 \mathrm{dd}(10.5,7.7)$ & & $4.65 \mathrm{dd}(10.6,8.6)$ & & $4.67 \mathrm{dd}(10.5,8.5)$ & & $4.65 \mathrm{dd}(10.6,8.8)$ & & $4.67 \mathrm{dd}(10.0,8.9)$ \\
\hline & & $\beta$-D-Glc & & $\beta$-D-Glc & & $\beta$-D-Glc & & $\beta$-D-Glc & & $\beta$-D-Glc \\
\hline 1 & 104.6 & $5.24 \mathrm{~d}(7.9)$ & 105.3 & $5.18 \mathrm{~d}(7.9)$ & 105.3 & $5.19 \mathrm{~d}(8.0)$ & 105.1 & $5.18 \mathrm{~d}(7.8)$ & 105.3 & $5.19 \mathrm{~d}(7.9)$ \\
\hline 2 & 81.1 & $4.27 \mathrm{dd}(7.9,8.5)$ & 81.3 & $4.33 \mathrm{dd}(7.9,8.7)$ & 81.1 & $4.40 \mathrm{dd}(8.0,8.5)$ & 81.3 & $4.33 \mathrm{dd}(7.8,8.5)$ & 81.1 & $4.40 \mathrm{dd}(7.9,8.5)$ \\
\hline 3 & 87.6 & $4.07 \mathrm{dd}(8.5,8.5)$ & 87.5 & $4.10 \mathrm{dd}(8.7,8.7)$ & 87.0 & $4.14 \mathrm{dd}(8.5,8.9)$ & 87.5 & $4.10 \mathrm{dd}(8.5,8.7)$ & 87.0 & $4.14 \mathrm{dd}(8.5,8.8)$ \\
\hline 4 & 70.7 & $3.82^{\mathrm{b}}$ & 70.7 & $3.81 \mathrm{dd}(8.7,9.1)$ & 70.8 & $3.81 \mathrm{dd}(8.9,9.2)$ & 70.7 & $3.81 \mathrm{dd}(8.7,8.7)$ & 70.8 & $3.81 \mathrm{dd}(8.8,9.1)$ \\
\hline 5 & 78.0 & $3.83^{\mathrm{b}}$ & 78.0 & 3.84 ddd $(9.1,6.8,3.0)$ & 78.0 & 3.88 ddd $(9.2,6.8,2.4)$ & 78.0 & 3.84 ddd $(8.7,6.3,3.1)$ & 78.0 & 3.88 ddd $(9.1,6.2,2.3)$ \\
\hline \multirow[t]{2}{*}{6} & 63.3 & $4.07^{\mathrm{b}}$ & 63.3 & $4.06 \mathrm{dd}(11.9,6.8)$ & 63.3 & $4.06 \mathrm{dd}(12.0,6.8)$ & 63.3 & $4.06 \mathrm{dd}(11.9,6.3)$ & 63.3 & $4.06 \mathrm{dd}(12.6,6.2)$ \\
\hline & & $4.50 \mathrm{dd}(9.8,2.2)$ & & $4.51 \mathrm{dd}(11.9,3.0)$ & & $4.52 \mathrm{dd}(12.0,2.4)$ & & $4.51 \mathrm{dd}(11.9,3.1)$ & & $4.52 \mathrm{dd}(12.6,2.3)$ \\
\hline & & $\beta$-D-Glc' & & $\beta$-D-Glc & & $\beta-\mathrm{D}-\mathrm{Glc} \mathrm{c}^{\prime}$ & & $\beta$-D-Glc & & $\beta$-D-Glc \\
\hline 1 & 104.6 & $5.51 \mathrm{~d}(8.0)$ & 104.7 & $5.51 \mathrm{~d}(8.0)$ & 104.4 & $5.59 \mathrm{~d}(7.5)$ & 104.7 & $5.51 \mathrm{~d}(7.9)$ & 104.4 & $5.59 \mathrm{~d}(7.4)$ \\
\hline 2 & 76.8 & $3.97 \mathrm{dd}(8.0,9.3)$ & 76.8 & $4.00 \mathrm{dd}(8.0,9.3)$ & 75.5 & $4.09^{\mathrm{b}}$ & 76.8 & $4.00 \mathrm{dd}(7.9,9.2)$ & 75.5 & $4.10^{\mathrm{b}}$ \\
\hline 3 & 83.9 & $4.23 \mathrm{dd}(9.2,9.2)$ & 83.5 & $4.23 \mathrm{dd}(9.3,9.3)$ & 87.1 & $4.06^{\mathrm{b}}$ & 83.5 & $4.23 \mathrm{dd}(9.2,9.2)$ & 87.1 & $4.06^{\mathrm{b}}$ \\
\hline 4 & 69.1 & $4.01 \mathrm{~m}$ & 69.6 & $4.13 \mathrm{dd}(9.3,7.4)$ & 69.5 & $4.06^{\mathrm{b}}$ & 69.6 & $4.12 \mathrm{dd}(9.2,8.9)$ & 69.5 & $4.06^{\mathrm{b}}$ \\
\hline 5 & 78.4 & $3.75 \operatorname{ddd}(9.3,4.9,2.3)$ & 78.8 & $3.79 \mathrm{~m}$ & 78.7 & $3.90 \mathrm{~m}$ & 78.8 & $3.79 \mathrm{~m}$ & 78.7 & $3.90 \mathrm{~m}$ \\
\hline \multirow[t]{3}{*}{6} & 62.8 & $4.38 \mathrm{dd}(11.9,4.9)$ & 62.6 & $4.37 \mathrm{dd}(11.9,3.4)$ & 62.5 & $4.30 \mathrm{dd}(11.8,4.8)$ & 62.6 & $4.36 \mathrm{dd}(11.8,3.0)$ & 62.5 & $4.30 \mathrm{dd}(12.3,4.8)$ \\
\hline & & $4.49 \mathrm{dd}(11.9,2.3)$ & & $4.52 \mathrm{dd}(11.9,2.3)$ & & $4.54 \mathrm{dd}(11.8,2.6)$ & & $4.52 \mathrm{dd}(11.8,1.7)$ & & $4.54 \mathrm{dd}(12.3,2.3)$ \\
\hline & & $\beta-\mathrm{D}-\mathrm{Xyl}$ & & $\beta-\mathrm{D}-\mathrm{Xyl}$ & & $\beta-\mathrm{D}-\mathrm{Xyl}$ & & $\beta-\mathrm{D}-\mathrm{Xyl}$ & & $\beta-\mathrm{D}-\mathrm{Xyl}$ \\
\hline 1 & 105.3 & $5.14 \mathrm{~d}(7.6)$ & 105.3 & $5.14 \mathrm{~d}(7.6)$ & 105.3 & $5.16 \mathrm{~d}(7.7)$ & 105.3 & $5.14 \mathrm{~d}(7.6)$ & 105.3 & $5.16 \mathrm{~d}(7.8)$ \\
\hline 2 & 75.7 & $3.95 \mathrm{dd}(7.6,8.8)$ & 75.6 & $3.95 \mathrm{dd}(7.6,8.8)$ & 75.5 & $3.96 \mathrm{dd}(7.7,8.3)$ & 75.6 & $3.95 \mathrm{dd}(7.6,8.9)$ & 75.6 & $3.96 \mathrm{dd}(7.8,8.3)$ \\
\hline 3 & 78.9 & $4.01 \mathrm{dd}(8.8,8.8)$ & 78.9 & $4.01 \mathrm{dd}(8.8,8.8)$ & 78.7 & $4.07 \mathrm{dd}(8.3,8.7)$ & 78.9 & $4.01 \mathrm{dd}(8.9,8.9)$ & 78.7 & $4.07 \mathrm{dd}(8.3,8.9)$ \\
\hline 4 & 71.0 & $4.12 \mathrm{~m}$ & 71.0 & $4.11 \mathrm{~m}$ & 71.1 & $4.12 \mathrm{~m}$ & 71.0 & $4.11 \mathrm{~m}$ & 71.1 & $4.12 \mathrm{~m}$ \\
\hline $5_{\mathrm{ax}}$ & 67.6 & $3.64 \mathrm{dd}(10.8,10.9)$ & 67.6 & $3.65 \mathrm{dd}(10.8,11.2)$ & 67.7 & $3.66 \mathrm{dd}(9.7,11.4)$ & 67.6 & $3.65 \mathrm{dd}(10.7,11.0)$ & 67.7 & $3.66 \mathrm{dd}(10.1,11.0)$ \\
\hline \multirow[t]{2}{*}{5 eq } & & $4.22 \mathrm{dd}(10.9,5.3)$ & & $4.22 \mathrm{dd}(11.2,5.1)$ & & $4.22 \mathrm{dd}(11.4,4.4)$ & & $4.22 \mathrm{dd}(11.0,5.0)$ & & $4.23 \mathrm{dd}(11.0,4.4)$ \\
\hline & & $\alpha$-L-Rha & & $\alpha$-L-Rha & & $\beta-\mathrm{D}-\mathrm{Xyl}^{\prime}$ & & $\alpha-$-Rha & & $\beta-\mathrm{D}-\mathrm{Xyl}$ \\
\hline 1 & 103.1 & $6.12 \mathrm{~d}(1.7)$ & 103.1 & $6.11 \mathrm{~d}(1.3)$ & 106.6 & $5.10 \mathrm{~d}(7.5)$ & 103.1 & $6.11 \mathrm{brs}$ & 106.6 & $5.11 \mathrm{~d}(7.4)$ \\
\hline 2 & 72.7 & $4.68 \mathrm{dd}(1.7,3.5)$ & 72.7 & $4.68 \mathrm{dd}(1.3,3.7)$ & 75.8 & $3.94 \mathrm{dd}(7.5,8.0)$ & 72.7 & $4.68 \mathrm{~d}(3.4)$ & 75.8 & $3.94 \mathrm{dd}(7.4,8.0)$ \\
\hline 3 & 73.0 & $4.49 \mathrm{dd}(3.5,8.9)$ & 72.9 & $4.48 \mathrm{dd}(3.7,8.9)$ & 78.2 & $4.07 \mathrm{dd}(8.0,8.7)$ & 72.9 & $4.48 \mathrm{dd}(3.4,8.8)$ & 78.2 & $4.08 \mathrm{dd}(8.0,8.7)$ \\
\hline 4 & 74.5 & $4.31 \mathrm{dd}(8.9,9.3)$ & 74.5 & $4.29 \mathrm{dd}(8.9,9.2)$ & 71.2 & $4.12 \mathrm{~m}$ & 74.5 & $4.29 \mathrm{dd}(8.8,9.2)$ & 71.2 & $4.13^{\mathrm{b}}$ \\
\hline $5_{a x} / 5$ & 70.1 & $4.91 \mathrm{dq}(9.3,6.2)$ & 70.1 & $4.93 \mathrm{dq}(9.2,6.1)$ & 67.5 & $3.57 \mathrm{dd}(11.2,9.5)$ & 70.1 & $4.93 \mathrm{dq}(9.2,6.2)$ & 67.6 & $3.57 \mathrm{dd}(11.2,9.5)$ \\
\hline \multirow[t]{2}{*}{$5_{\text {eq }} / 6$} & 19.0 & $1.64 \mathrm{~d}(6.2)$ & 19.0 & $1.65 \mathrm{~d}(6.1)$ & & $4.23 \mathrm{dd}(11.2,4.4)$ & 19.0 & $1.65 \mathrm{~d}(6.2)$ & & $4.23 \mathrm{dd}(11.2,4.3)$ \\
\hline & & & & & & & & $26-O-\beta-D-G l c^{\prime \prime}$ & & $26-O-\beta-\mathrm{D}-G \mathrm{Cl}^{\prime \prime}$ \\
\hline 1 & & & & & & & 105.4 & $4.83 \mathrm{~d}(7.8)$ & 105.4 & $4.83 \mathrm{~d}(7.8)$ \\
\hline 2 & & & & & & & 75.6 & $4.04 \mathrm{dd}(7.8,8.2)$ & 75.6 & $4.04 \mathrm{dd}(7.8,8.3)$ \\
\hline 3 & & & & & & & 79.0 & $4.25^{\mathrm{b}}$ & 79.0 & $4.25^{\mathrm{b}}$ \\
\hline 4 & & & & & & & 72.1 & $4.24^{\mathrm{b}}$ & 72.1 & $4.24^{\mathrm{b}}$ \\
\hline 5 & & & & & & & 78.9 & $3.96 \mathrm{~m}$ & 78.9 & $3.96 \operatorname{ddd}(8.5,4.5,2.5)$ \\
\hline 6 & & & & & & & 63.2 & $4.40 \mathrm{dd}(12.0,4.3)$ & 63.2 & $4.40 \mathrm{dd}(12.0,4.5)$ \\
\hline & & & & & & & & $4.56 \mathrm{dd}(12.0,2.2)$ & & $4.57 \mathrm{dd}(12.0,2.5)$ \\
\hline
\end{tabular}

\footnotetext{
a Assignments were confirmed by DQF-COSY, 1D-TOCSY, HSQC, HSQC-TOCSY and HMBC experiments.
}

a Assignments
b Overlapped. 
and $\mathrm{C}-3(\delta 84.5) / \mathrm{H}-3(\delta 3.82)$ of the aglycone moiety. These results revealed that the sugar chain was the same as in Agabrittonoside D (9) (Macías et al., 2007).

After acid hydrolysis of $\mathbf{1}$, the absolute configurations of the sugars were determined by a slight modification of the method reported by Tanaka et al. (2007). Sugars were converted into the thiazolizine derivatives and then into the arylthiocarbamate using L-cysteine methyl ester and o-tolylisothiocyanate. The reaction mixture was then directly analyzed by UPLC-UV-SRM/MS and the retention times $(R t)$ were compared with values obtained for derivatives of authentic samples of each D- or L-sugar. In this way, D-galactose, D-glucose, D-xylose and L-rhamnose were identified.

The structure of 1 was established as Kammogenin-3-O-\{ $\alpha-\mathrm{L}-$ rhamnopyranosyl-( $1 \rightarrow 3)-O-\beta$-D-glucopyranosyl-( $1 \rightarrow 2)-O-[\beta$-D-xylopyranosyl-( $1 \rightarrow 3)$ ]-O- $\beta$-D-glucopyranosyl-( $1 \rightarrow 4)-O-\beta$-D-galactopyran oside\}. This compound has not been described previously and we propose to name it Magueyoside F.

Compound 2 was isolated as a white amorphous solid and has the molecular formula $\mathrm{C}_{56} \mathrm{H}_{88} \mathrm{O}_{27}$. The ${ }^{1} \mathrm{H}$ NMR spectrum of 2 showed five anomeric signals at $\delta 4.86,5.14,5.18,5.51$ and 6.11 (Table 2) and these were correlated in the HSQC spectrum with carbons at $\delta$ 103.2, 105.3, 105.3, 104.7 and 103.1, which were identified as being due to $\beta$-D-galactopyranosyl, $\beta$-D-xylopyranosyl, $\beta$-D-glucopyranosyl, $\beta$-D-glucopyranosyl and $\alpha$-L-rhamnopyranosyl units, respectively. A rigorous study of the HMBC and ROESY correlations allowed us to establish the sequence of the sugars chain in compound $\mathbf{2}$ as being the same as in $\mathbf{1}$. Despite the fact that ${ }^{1} \mathrm{H}$ and ${ }^{13} \mathrm{C}$ NMR data for rings C-F of the aglycone moieties of $\mathbf{1}$ and $\mathbf{2}$ were almost superimposable (Table 1), significant differences for ring A were observed. Analysis of the 2D TOCSY, ${ }^{1} \mathrm{H}-{ }^{1} \mathrm{H}$ COSY and HSQC-TOCSY spectra allowed the spin system for ring $A$ to be identified as $\left[-\mathrm{CH}_{2}-\mathrm{CH}_{2}-\mathrm{CHOH}-\mathrm{CH}_{2}-\right]$ with only one oxygenated $s p^{3}$ carbon $(\delta 78.3, \mathrm{C}-3)$. The lack of a hydroxyl group at C-2 of the aglycone moiety of $\mathbf{2}$ is consistent with the molecular formula. Therefore, the aglycone moiety of $\mathbf{2}$ was elucidated as (25R)spirost-5-en-3 $\beta$-ol-12-one, which is known as gentrogenin (Wall et al., 1957; Huang et al., 1997; Xie et al., 2009). Based on the evidence outlined above, the structure of $\mathbf{2}$ was finally determined as gentrogenin-3-O-\{ $\alpha$-L-rhamnopyranosyl-( $1 \rightarrow 3)-O-\beta$-D-glucopyranosyl-( $1 \rightarrow 2)-O$-[ $\beta$-D-xylopyranosyl- $(1 \rightarrow 3)]-O-\beta$-D-glucopyranosyl -( $1 \rightarrow 4)-O-\beta$-D-galactopyranoside $\}$, which has not been reported previously and we propose to name this compound Magueyoside G.

The spectroscopic data for compound $3\left(\mathrm{C}_{55} \mathrm{H}_{86} \mathrm{O}_{27}\right)$ showed that it was a spirostane pentaglycoside that is closely related to 2, except for one terminal monosaccharide constituent. The ${ }^{1} \mathrm{H}$ NMR spectrum of $\mathbf{3}$ showed, instead of the anomeric resonance signal of the $\alpha$-rhamnopyranosyl unit at $\delta 6.11$, an anomeric doublet at $\delta 5.10(J=7.5 \mathrm{~Hz})$, which was identified as being due to a $\beta$-Dxylopyranosyl unit. HMBC and ROESY correlations for $\mathbf{3}$ suggested the same sugars chain as in Agabrittonoside A (10) (Macías et al., 2007) and Magueyoside A (7) (Pérez et al., 2013). Consequently, the structure of compound 3 was elucidated as gentrogenin-3-O$\{\beta$-D-xylopyranosyl-( $1 \rightarrow 3)-O-\beta$-D-glucopyranosyl- $(1 \rightarrow 2)-O$-[ $\beta$-D-xy lopyranosyl-( $1 \rightarrow 3)$ ]-O- $\beta$-D-glucopyranosyl-( $1 \rightarrow 4)-O$ - $\beta$-D-galactopy ranoside\}, which has not been described previously and we propose to name this compound Magueyoside $\mathrm{H}$.

Compound 4 has the molecular formula $\mathrm{C}_{62} \mathrm{H}_{100} \mathrm{O}_{33}$ and this suggests an extra hexosyl unit plus a hydroxyl group in comparison with 2. The ${ }^{1} \mathrm{H}$ NMR signal assignments for the aglycone moiety of $\mathbf{4}$ were in good agreement with those of $\mathbf{2}$, with the exception of the signals for rings $\mathrm{E}$ and $\mathrm{F}$. The ${ }^{13} \mathrm{C}$ NMR data for the aglycone moiety of 4 (Table 1 ) suggest a furostane skeleton with the usual hemiketalic function at C-22 $(\delta 111.2)$. A clear diagnostic cross peak was observed in the ROESY spectrum between the H-20 ( $\delta$ 2.22) and $\mathrm{H}_{2}-23$ protons $(\delta 2.05,2 \mathrm{H})$ and this provided evidence of an $\alpha$-orientation of the hydroxyl group at C-22 and a $22 R$ configuration (Macías et al., 2010). The 25R configuration was deduced according to Agrawal's rule, which establishes a $25 R$ configuration when the difference in the chemical shifts between geminal protons of the glycosyloxy methylene $\mathrm{H}_{2}-26\left(\Delta_{\mathrm{ab}}=\delta_{\mathrm{a}}-\delta_{\mathrm{b}}\right)$ is less than 0.48 (Agrawal, 2004, 2005). The ${ }^{1} \mathrm{H}$ NMR spectrum of $\mathbf{4}$ showed an additional anomeric doublet at $\delta 4.83(J=7.8 \mathrm{~Hz}$ ) (Table 2), which was identified as being due to a $\beta$-D-glucopyranosyl unit $\left(\mathrm{Glc}^{\prime \prime}\right)$. The HMBC cross peak between $\mathrm{H}-1_{\mathrm{Glc}^{\prime \prime}}$ and the carbon signal at $\delta 75.6$ (C-26 of the aglycone), as well as ROESY correlations between this anomeric proton and the signals for $\mathrm{H}_{2}-26$ ( $\delta 3.96$ and $\delta 3.62$ ), confirmed the presence of a $26-0$-glucosylated furostanol saponin. Thus, the structure of compound 4 was elucidated as (25R)-26-O- $\beta$ D-glucopyranosylfurost-5-en-3 $\beta, 22 \alpha, 26$-triol-12-one $3-O-\{\alpha$-L-rha mnopyranosyl-( $1 \rightarrow 3)-O-\beta$-D-glucopyranosyl- $(1 \rightarrow 2)-O-[\beta$-D-xylopyranosyl-( $1 \rightarrow 3)$ ]-O- $\beta$-D-glucopyranosyl-( $1 \rightarrow 4)-O-\beta$-D-galactopyranoside , which is a $26-0$-glucosylated furostanol derivative of 2 . This compound has not been reported previously and we propose to name it Magueyoside I.

Compound $5\left(\mathrm{C}_{61} \mathrm{H}_{98} \mathrm{O}_{33}\right)$ showed spectroscopic features similar to those of 4 . The ${ }^{1} \mathrm{H}$ and ${ }^{13} \mathrm{C}$ NMR assignments for the aglycone moiety of $\mathbf{5}$ (Table 1 ) were consistent with those of $\mathbf{4}$, while the NMR data for the glycosidic portion (Table 2) were consistent with those of $\mathbf{3}$. Accordingly, the structure of $\mathbf{5}$ was identified as a 26-O-glucosylated furostanol derivative of $\mathbf{3}$. Thus, compound $\mathbf{5}$ was identified as (25R)$26-O$ - $\beta$-D-glucopyranosylfurost-5-en-3 $\beta, 22 \alpha, 26$-triol-12-one $3-O-\{\beta$ -D-xylopyranosyl-( $1 \rightarrow 3)-O-\beta$-D-glucopyranosyl-( $1 \rightarrow 2)-O$-[ $\beta$-D-xylopyranosyl-( $1 \rightarrow 3)$ ]-O- $\beta$-D-glucopyranosyl- $(1 \rightarrow 4)-O$ - $\beta$-D-galactopyranoside\}. This saponin has not been described previously and we propose to name it Magueyoside J.

It is interesting to note that only three saponins isolated from $A$. offoyana flowers (Pérez et al., 2013) were found in the leaves. Regarding sugar moieties, rhamnose derivatives were not found in the flowers. Only one saponin with a short sugar chain was isolated per studied organ. The compound present in the leaves was the 23-hydroxylated derivative of saponin found in the flowers. This fact suggests a possible role of saponins in the flowering stage or lifespan of Agave species and this possibility warrants further investigation.

\subsection{Bioassay of extracts, fractions and saponins}

In order to carry out the initial bioactivity evaluation, extracts and fractions were assayed on etiolated wheat coleoptiles at 800 , 400 and $200 \mathrm{ppm}$ (Fig. 2). This is a rapid preliminary test that shows a good correlation with the phytotoxicity of saponins (Pérez et al., 2013). Fractions F3 to F6 showed the best inhibition profiles and they were therefore selected for the phytotoxicity evaluation.

The assay was performed using $L$. sativa $\mathrm{L}$. (lettuce), Lycopersicum esculentum Will. (tomato), Lepidium sativum L. (cress), and Allium cepa L. (onion) as standard target species (STS) (Macías et al., 2000). Significant effects were observed only on the root growth of STS, especially in lettuce (Fig. 3). The inhibition values for fractions F4-F6 on the root growth of lettuce at $800 \mathrm{ppm}$ were higher than those of Logran ${ }^{\circledR}$ (Fig. 2A). Strong inhibition profiles were also obtained for all tested fractions, including F3 on onion (Fig. 2D).

Based on the available quantities of the saponins, lettuce was chosen as a model plant to test their phytotoxicities; at 333, 100, 33, 10, 3.3 and $1 \mu \mathrm{M}$ (Fig. 4). Magueyoside A (7), Magueyoside B (8) and Agabrittonoside A (10) were excluded from this test because they had been assayed previously under identical conditions (Pérez et al., 2013).

All of the saponins tested showed a significant effect on root growth as fractions with lower $\mathrm{IC}_{50}$ values than $\operatorname{Logran}^{\circledR}\left(\mathrm{IC}_{50}\right.$ 


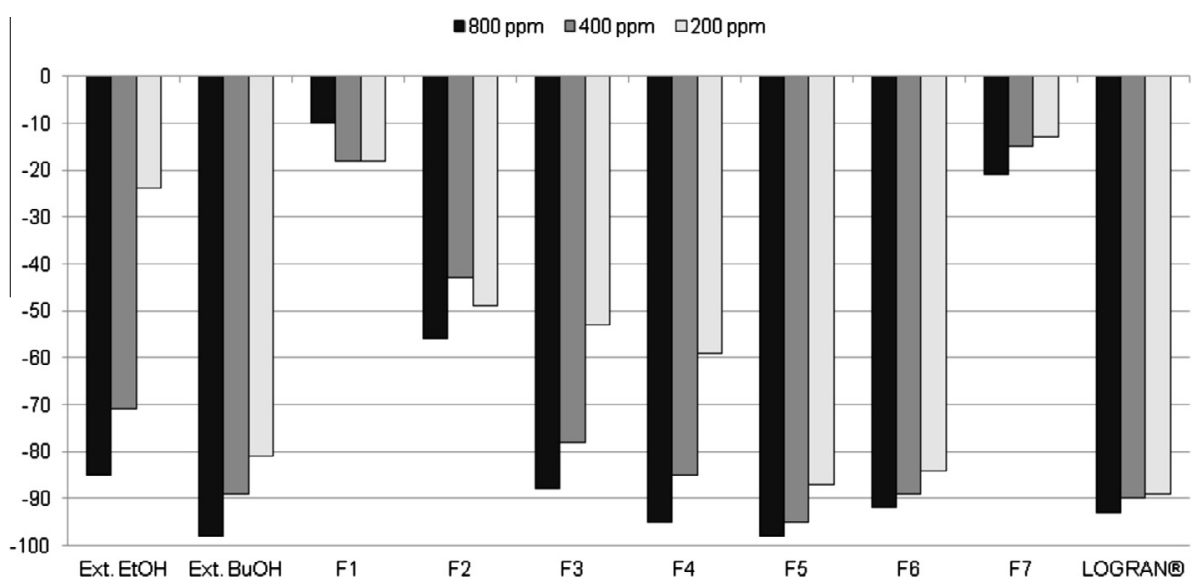

Fig. 2. Effect of extracts and fractions of A. offoyana leaves on the elongation of etiolated wheat coleoptiles. Values are expressed as percentage of the control.

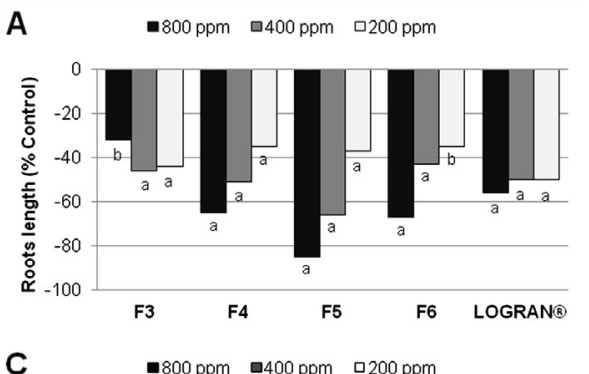

B $\quad \mathbf{Q} 800 \mathrm{ppm} \quad \square 400 \mathrm{ppm} \quad \square 200 \mathrm{ppm}$
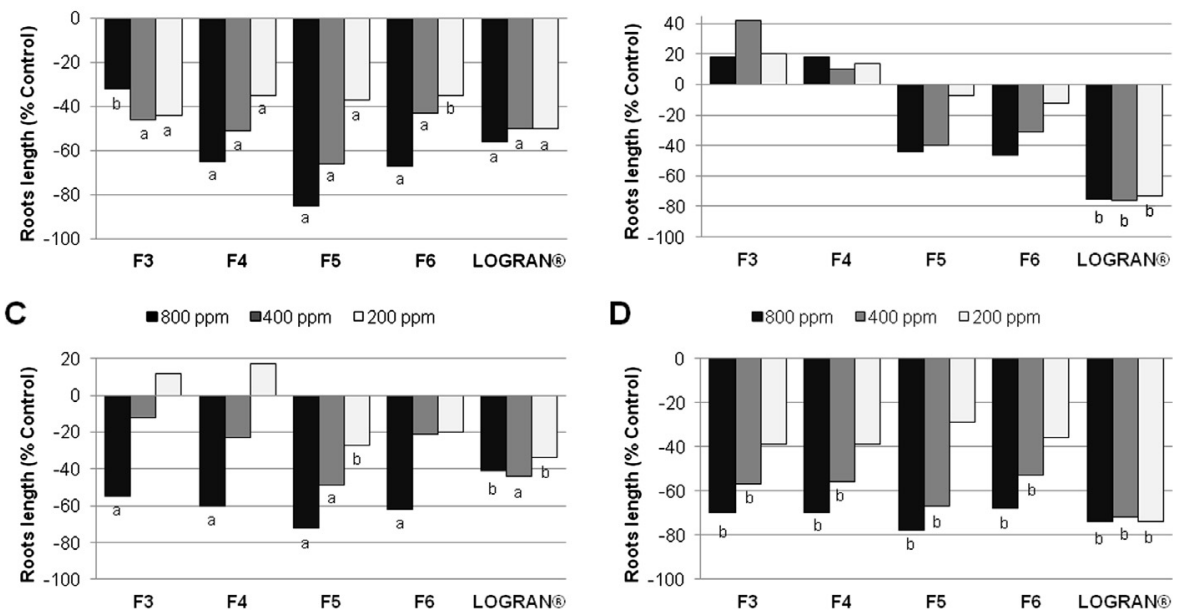

D $\quad \mathbf{2} 800 \mathrm{ppm} \quad \square 400 \mathrm{ppm} \quad \square 200 \mathrm{ppm}$

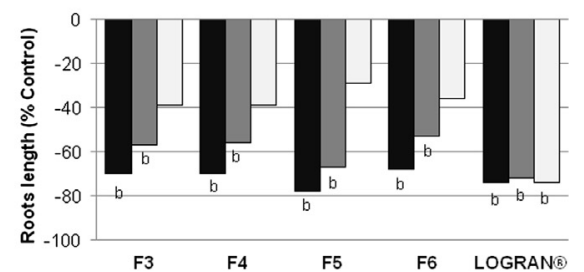

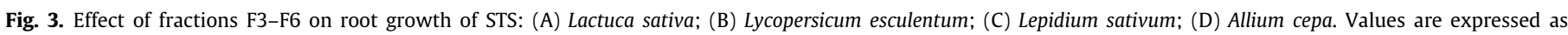

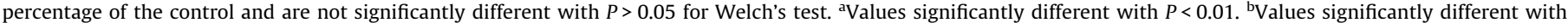
$0.01<P<0.05$.

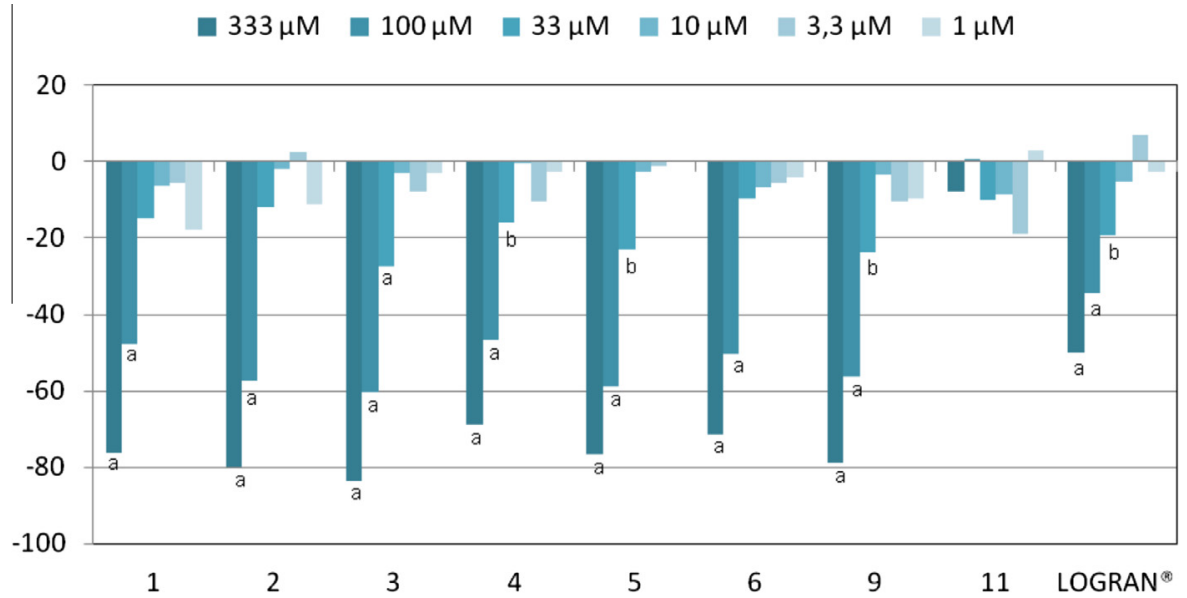

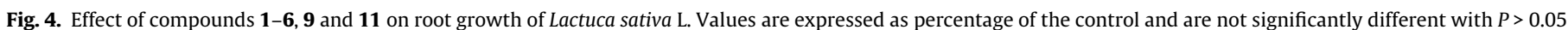
for Welch's test. ${ }^{a}$ Values significantly different with $P<0.01$. ${ }^{b}$ Values significantly different with $0.01<P<0.05$.

$251.1 \mu \mathrm{M}$ ), except for Cantalasaponin-1 (11) (Table 3). As a result, a long glycosidic chain linked at C-3 of the aglycone moiety was suggested as a key factor for phytotoxicity. Although the bioactivities of compounds 1-6 and 9 were not significantly different $\left(\mathrm{IC}_{50}\right.$ in the range $85-160 \mu \mathrm{M}$ ) some points should be highlighted. A $\beta$-Dxylopyranosyl unit instead of an $\alpha$-L-rhamnopyranosyl unit at the 
Table 3

Phytotoxicity of compounds 1-6, 9 and 11 on roots of Lactuca sativa $\mathrm{L}$.

\begin{tabular}{ccl}
\hline Compounds & $\mathrm{IC}_{50}(\mu \mathrm{M})$ & $r^{2}$ \\
\hline $\mathbf{1}$ & 159.6 & 0.9865 \\
$\mathbf{2}$ & 101.4 & 0.9771 \\
$\mathbf{3}$ & 90.4 & 0.9949 \\
$\mathbf{4}$ & 137.7 & 0.9632 \\
$\mathbf{5}$ & 89.5 & 0.9855 \\
$\mathbf{6}$ & $135.5^{*}$ & 0.9832 \\
$\mathbf{9}$ & 109.6 & 0.9844 \\
$\mathbf{1 1}$ & n.d & n.d \\
LOGRAN $^{\circledR}$ & $251.1^{*}$ & 0.9778
\end{tabular}

* The data were not adjusted to the dose-response curve; n.d, not determined.

end of glycosidic chains may slightly enhance the phytotoxicity, as shown by comparison of compounds 3 ( IC $\left._{50} 90.4 \mu \mathrm{M}\right), 2$ ( $\mathrm{IC}_{50}$ $101.4 \mu \mathrm{M}), 5\left(\mathrm{IC}_{50} 89.5 \mu \mathrm{M}\right)$ and $4\left(\mathrm{IC}_{50} 137.7 \mu \mathrm{M}\right)$. In contrast, the relationship between aglycone structure and phytotoxicity remains unclear. Comparison of the activity of spirostane and furostane saponins also highlighted an interesting result as the difference between them was negligible.

Previous studies on the mode of action of phytotoxic saponins mainly concern oleanane-type compounds (Oleszek, 1993; Waller et al., 1996; Hernández Carlos et al., 2011; Scognamiglio et al., 2012). According to Marchaim et al. (1974) the hydrophobic moieties of alfalfa saponin molecules combine with membrane cholesterol in the cell of cotton seeds, causing structural changes in the membranes that result in increased swelling at the fringe of the living cell wall. The ability of saponins to interact with membrane cholesterol, which in turn leads to membrane destabilization, is the classical explanation for their bioactivity. In the case of steroidal saponins, this mechanism takes place in the haemolytic action where furostane-types are generally inactive because the hydrophobic moiety is modified. However, our data do not fully fit the proposed mechanism of saponin membrane activity, since the furostane saponins showed similar phytotoxicities to those of their spirostane analogs. This behavior has also been found for monodesmoside and bisdesmoside oleanane-type saponins (Oleszek, 1993, 2000). Similarly, the structure/cytotoxicity relationship between steroidal saponins was reviewed recently and it was established that there is no clear correlation between haemolytic activity and cytotoxicity (Podolak et al. 2010). In the same way, the SAR data that refer to haemolysis could not be directly extrapolated to relationships for cytotoxic activity.

The discrepancy in phytotoxic activity between furostane and spirostane saponins may be a simple exception or, perhaps, it could indicate a different mode of action. The results presented in this paper show that saponins of $A$. offoyana leaves generally have stronger phytotoxic activity than Logran ${ }^{\circledR}$ on $L$. sativa L. These compounds can therefore be considered as potential herbicides and they warrant further investigation.

\section{Experimental}

\subsection{General experimental procedures}

Optical rotations were determined on a Perkin-Elmer 241 polarimeter $\left(589 \mathrm{~nm}, 20^{\circ} \mathrm{C}\right) .1 \mathrm{D}$ and 2D NMR spectra were recorded on a Bruker Avance III HD Ascend ${ }^{\mathrm{TM}}-500$ spectrometer equipped with $5 \mathrm{~mm}{ }^{1} \mathrm{H}\left\{{ }^{109} \mathrm{Ag}_{-}{ }^{31} \mathrm{P}\right\}$ broadband inverse (BBI) z-gradient probe. ${ }^{1} \mathrm{H}(500.18 \mathrm{MHz})$ and ${ }^{13} \mathrm{C}(125.77 \mathrm{MHz})$ NMR spectra were recorded in pyridine- $d_{5}$ at $25{ }^{\circ} \mathrm{C}$ and chemical shifts are given on the $\delta$ scale referenced to residual pyridine, $\delta_{\mathrm{H}} 8.74,7.58,7.22$ and $\delta_{\mathrm{C}} 150.35,135.91,123.87 .1 \mathrm{D}\left({ }^{13} \mathrm{C}\right)$ spectra were obtained using the uniform driven equilibrium Fourier transform sequence (UDEFT) (Piotto et al., 2006). Adiabatic pulse sequences using gradients were applied and all 2D spectra, except for HMBC, were recorded in the phase-sensitive mode. Exact masses were measured on a UPLC-QTOF ESI (Waters Synapt G2, Manchester, UK) high resolution mass spectrometer (HRESI-TOFMS). Mass spectra were recorded in negative or positive ion mode in the $m / z$ range 100-2000, with a mass resolution of 20000 and an acceleration voltage of $0.7 \mathrm{kV}$. MS/MS fragmentation patterns of saponins were obtained using a Thermo LCQ Advantage Max ion-trap mass spectrometer. Samples were injected by direct infusion. The spectrometer was operated in the negative electrospray mode with the following parameters: spray voltage $3.9 \mathrm{kV}$, capillary voltage $-47 \mathrm{~V}$, tube lens offset $-60 \mathrm{~V}$ and capillary temperature $240{ }^{\circ} \mathrm{C}$. Semi-preparative HPLC in isocratic mode was performed on a chromatographic system equipped with Gilson 321 pump, a Gilson GX-271 liquid handler with a $2 \mathrm{~mL}$ sample loop, a Gilson Prep ELS $^{\mathrm{TM}}$ II detector and a semi-preparative reversed phase Atlantis Prep T3, $5 \mu \mathrm{m}$, $(250 \times 10 \mathrm{~mm}$, i.d $)$ column or an Agilent Eclipse Plus C18, $3.5 \mu \mathrm{m},(150 \times 4.6 \mathrm{~mm}$, i.d $)$ analytical column.

\subsection{Plant material}

Leaves of $A$. offoyana were collected in January 2008 by botanist Dr. Alfredo Noa in Palenque, Remedios City, north of Villa Clara province, Cuba. A voucher specimen was deposited in the Herbarium Dr. Alberto Alonso Triana of the Universidad Central 'Marta Abreu' de Las Villas, Cuba (number HPVC 3017).

\subsection{Extraction and isolation}

Dried and powdered leaves $(1 \mathrm{~kg})$ were extracted three times with ethanol/water (7:3) for $48 \mathrm{~h}$ by maceration at room temperature. The solvent was removed under reduced pressure and the syrupy residue (14.7\%) was suspended in distilled water, defatted with $n$-hexane, and then extracted with water-saturated $n$ - $\mathrm{BuOH}$. After removing the solvent, $15 \mathrm{~g}$ of $n-\mathrm{BuOH}$ extract $(12.9 \%$ of ethanolic extract) were purified by VLC on LiChrospher RP-18 and eluted with mixtures of $\mathrm{MeOH} / \mathrm{H}_{2} \mathrm{O}$ to give seven fractions (F1: 1.42 g, F2: 1.19 g, F3: 3.64 g, F4: 2.13 g, F5: 2.14 g, F6: $1.45 \mathrm{~g}$ and F7: $1.22 \mathrm{~g})$.

F3 was subjected to MPLC on a Büchi 861 apparatus with a column filled with 40-63 $\mu$ m LiChrospher RP-18, using $\mathrm{Me}_{2} \mathrm{CO} / \mathrm{H}_{2} \mathrm{O}$ (3:7) as mobile phase. Six milliliter fractions were collected and checked by TLC on RP-18 $\mathrm{F}_{254 \mathrm{~s}}$, developed with $\mathrm{Me}_{2} \mathrm{CO} / \mathrm{H}_{2} \mathrm{O}$ (4:6), then sprayed with Oleum reagent and heated at $150{ }^{\circ} \mathrm{C}$. Fractions with similar profiles were combined to give 9 fractions, of which F3-2 and F3-4 contained the major saponins. Further fractionation of F3-2 by HPLC on an analytical $\mathrm{C} 18$ column with $15.5 \%$ of solvent B $\left(\mathrm{CH}_{3} \mathrm{CN}\right.$ containing $\left.0.2 \% \mathrm{HCO}_{2} \mathrm{H}\right)$ in solvent $\mathrm{A}\left(\mathrm{H}_{2} \mathrm{O}\right.$ containing $\left.0.2 \% \mathrm{HCO}_{2} \mathrm{H}\right)$ as the mobile phase, $1.7 \mathrm{~mL} / \mathrm{min}$ and $40{ }^{\circ} \mathrm{C}$, yielded compounds $\mathbf{4}(9.2 \mathrm{mg})$ and $\mathbf{5}(8.7 \mathrm{mg})$. Under the same conditions, fractionation of F3-4 gave compound 6 ( $4.2 \mathrm{mg})$.

Fractionation of F4 by MPLC under the same conditions as described above, but using $\mathrm{Me}_{2} \mathrm{CO} / \mathrm{H}_{2} \mathrm{O}$ (5:5) as the eluent gave four further fractions. Fraction F4-3 was the major fraction. Subsequent purification of F4-3 by HPLC on a semi-preparative $\mathrm{C} 18$ column using $34 \%$ of solvent B in solvent A as mobile phase, $5 \mathrm{~mL} / \mathrm{min}$ and $35^{\circ} \mathrm{C}$, yielded compounds 1 (4.6 mg), 7 (4.8 mg), 8 (4.7 mg) and 11 (5.0 mg).

F5 was subjected to MPLC with a mixture of $\mathrm{Me}_{2} \mathrm{CO} / \mathrm{MeOH} / \mathrm{H}_{2} \mathrm{O}$ (3:3:4) as the mobile phase to give three additional fractions, of which F5-1 was then purified by HPLC on semi-preparative C18 column with $37 \%$ of solvent B in solvent A as mobile phase, $5 \mathrm{~mL} / \mathrm{min}$ and $30^{\circ} \mathrm{C}$, to give compounds $2(9.6 \mathrm{mg})$ and $3(10.1 \mathrm{mg})$. 
Finally, F6 was directly fractionated by HPLC on a semi-preparative C18 column, with $39 \%$ of solvent B in solvent A as mobile phase, $5 \mathrm{~mL} / \mathrm{min}$ and $39^{\circ} \mathrm{C}$, to give compounds $\mathbf{9}(8.1 \mathrm{mg})$ and $\mathbf{1 0}$ (3.5 mg).

\subsection{Compound 1}

$[\alpha]_{\mathrm{D}}^{20}-47.8(\mathrm{MeOH}, \quad c \quad 0.1)$. HRESI-TOFMS, $m / z 1231.5345$ $[\mathrm{M}+\mathrm{Na}]^{+}$(calcd. for $\mathrm{C}_{56} \mathrm{H}_{88} \mathrm{O}_{28} \mathrm{Na}, 1231.5360$ ). ESI-MS (negative ion mode), $m / z 1207[\mathrm{M}-\mathrm{H}]^{-}$, which was fragmented in the MS/ MS to give $m / z 1075[\mathrm{M}-\mathrm{H}-132]^{-}, 929[\mathrm{M}-\mathrm{H}-132-146]^{-}, 767$ $[\mathrm{M}-\mathrm{H}-132-146-162]^{-}, 605[\mathrm{M}-\mathrm{H}-132-146-162-162]^{-}$. For ${ }^{1} \mathrm{H}$ and ${ }^{13} \mathrm{C}$ NMR data see Tables 1 and 2.

\subsection{Compound 2}

$[\alpha]_{\mathrm{D}}^{20}-46.4(\mathrm{MeOH}, \quad c \quad 0.1)$. HRESI-TOFMS, $m / z \quad 1191.5425$ $[\mathrm{M}-\mathrm{H}]^{-}$(calcd. for $\mathrm{C}_{56} \mathrm{H}_{87} \mathrm{O}_{27}, 1191.5435$ ). ESI-MS (negative ion mode), $m / z 1191[\mathrm{M}-\mathrm{H}]^{-}$, which was fragmented in the MS/MS to give $m / z \quad 1059[\mathrm{M}-\mathrm{H}-132]^{-}, 913[\mathrm{M}-\mathrm{H}-132-146]^{-}, 751$ $[\mathrm{M}-\mathrm{H}-132-146-162]^{-}, 589$ [M-H-132-146-162-162 $]^{-}$. For ${ }^{1} \mathrm{H}$ and ${ }^{13} \mathrm{C}$ NMR data see Tables 1 and 2.

\subsection{Compound 3}

$[\alpha]_{\mathrm{D}}{ }^{20}-45.6(\mathrm{MeOH}, \quad c \quad 0.1)$. HRESI-TOFMS, $m / z 1177.5294$ $[\mathrm{M}-\mathrm{H}]^{-}$(calcd. for $\mathrm{C}_{55} \mathrm{H}_{85} \mathrm{O}_{27}, 1177.5278$ ). ESI-MS (negative ion mode), $m / z 1177[\mathrm{M}-\mathrm{H}]^{-}$, which was fragmented in the MS/MS to give $\mathrm{m} / \mathrm{z} 1045[\mathrm{M}-\mathrm{H}-132]^{-}, 883[\mathrm{M}-\mathrm{H}-132-162]^{-}, 751$ $[\mathrm{M}-\mathrm{H}-132-162-132]^{-}, 589[\mathrm{M}-\mathrm{H}-132-162-132-162]^{-}$. For ${ }^{1} \mathrm{H}$ and ${ }^{13} \mathrm{C}$ NMR data see Tables 1 and 2.

\subsection{Compound $\mathbf{4}$}

$[\alpha]_{\mathrm{D}}{ }^{20}-37.2(\mathrm{MeOH}, c \quad 0.1)$. HRESI-TOFMS, $m / z 1371.6042$ $[\mathrm{M}-\mathrm{H}]^{-}$(calcd. for $\mathrm{C}_{62} \mathrm{H}_{99} \mathrm{O}_{33}, 1371.6069$ ). ESI-MS (negative ion mode), $m / z 1371[\mathrm{M}-\mathrm{H}]^{-}$, which was fragmented in the MS/MS to give $m / z 1239[\mathrm{M}-\mathrm{H}-132]^{-}, 1093[\mathrm{M}-\mathrm{H}-132-146]^{-}, 931$ $[\mathrm{M}-\mathrm{H}-132-146-162]^{-}, 769[\mathrm{M}-\mathrm{H}-132-146-162-162]^{-}$. For ${ }^{1} \mathrm{H}$ and ${ }^{13} \mathrm{C}$ NMR data see Tables 1 and 2.

\subsection{Compound $\mathbf{5}$}

$[\alpha]_{\mathrm{D}}^{20}-29.2(\mathrm{MeOH}, \quad c \quad 0.1)$. HRESI-TOFMS, $m / z 1357.5918$ $[\mathrm{M}-\mathrm{H}]^{-}$(calcd. for $\mathrm{C}_{61} \mathrm{H}_{97} \mathrm{O}_{33}, 1357.5912$ ). ESI-MS (negative ion mode), $m / z 1357[\mathrm{M}-\mathrm{H}]^{-}$, which was fragmented in the MS/MS to give $m / z 1225[\mathrm{M}-\mathrm{H}-132]^{-}, 1063[\mathrm{M}-\mathrm{H}-132-162]^{-}, 931$ $[\mathrm{M}-\mathrm{H}-132-162-132]^{-}, 769[\mathrm{M}-\mathrm{H}-132-162-132-162]^{-}$. For ${ }^{1} \mathrm{H}$ and ${ }^{13} \mathrm{C}$ NMR data see Tables 1 and 2.

\subsection{Compound 6}

$[\alpha]_{D}^{20}-43.6(\mathrm{MeOH}, \quad c \quad 0.1)$. HRESI-TOFMS, $m / z \quad 1359.6084$ $[\mathrm{M}-\mathrm{H}]^{-}$(calcd. for $\left.\mathrm{C}_{61} \mathrm{H}_{99} \mathrm{O}_{33}, 1359.6069\right)$.

\subsection{Compound $\mathbf{9}$}

$[\alpha]_{\mathrm{D}}^{20}-54.0(\mathrm{MeOH}, \quad c \quad 0.1)$. HRESI-TOFMS, $m / z 1193.5582$ $[\mathrm{M}-\mathrm{H}]^{-}$(calcd. for $\mathrm{C}_{56} \mathrm{H}_{89} \mathrm{O}_{27}, 1193.5591$ ).

\subsection{Acid hydrolysis of saponins}

Compounds 1-6 and $\mathbf{9}$ (1 mg each) were treated with $2 \mathrm{M} \mathrm{HCl}$ in 1,4-dioxane $/ \mathrm{H}_{2} \mathrm{O}(1: 1, \mathrm{v} / \mathrm{v}, 2 \mathrm{~mL})$ at $95^{\circ} \mathrm{C}$ for $4 \mathrm{~h}$. After cooling, the solvent was removed with a stream of $\mathrm{N}_{2}$. The dry residue was suspended in water and aglycones were extracted with ethyl acetate
$(3 \times 2 \mathrm{~mL})$. The aqueous layer containing sugars was neutralized with Amberlite IRA-400 $\left(\mathrm{OH}^{-}\right.$form), dried under $\mathrm{N}_{2}$ and stored prior to analysis.

\subsection{Determination of the absolute configuration of sugars}

The absolute configurations of monosaccharide constituents of compounds 1-6 and 9 were determined according to the method reported by Tanaka et al. (2007) with slight modifications. Sugars from each sample were dissolved in pyridine $(0.5 \mathrm{~mL})$ containing L-cysteine methyl ester hydrochloride $(1 \mathrm{mg})$ and heated at $60{ }^{\circ} \mathrm{C}$ for $1 \mathrm{~h}$; $o$-tolyl isothiocyanate $(2 \mu \mathrm{L})$ was then added and the mixture was heated at $60^{\circ} \mathrm{C}$ for $1 \mathrm{~h}$. Each reaction mixture was directly analyzed on a Waters UPLC system with a Waters Acquity PDA detector (at $245 \mathrm{~nm}$ ) and Waters triple quadrupole detector (TQD) operated in selected reaction monitoring (SRM) positive electrospray mode (capillary voltage $-3.2 \mathrm{kV}$, cone voltage $-30 \mathrm{~V}$, collision energy $-15 \mathrm{~V}$ ) using the following transitions: $m / z 447>298$ for hexoses, $m / z 431>282$ for deoxyhexoses and $m / z 417>268$ for pentoses. The software used for acquisition and data processing was MassLynx v4.1. An Acquity BEH C18, $1.7 \mu \mathrm{m}$ $(100 \times 2.1 \mathrm{~mm}$ i.d) (Waters) column was used; 16 min linear gradient from $5 \%$ to $50 \%$ of solvent $\mathrm{B}\left(\mathrm{CH}_{3} \mathrm{CN}\right.$ containing $\left.0.1 \% \mathrm{HCO}_{2} \mathrm{H}\right)$ in solvent $\mathrm{A}\left(\mathrm{H}_{2} \mathrm{O}\right.$ containing $\left.0.1 \% \mathrm{HCO}_{2} \mathrm{H}\right), 0.35 \mathrm{~mL} / \mathrm{min}$ at $30^{\circ} \mathrm{C}$. The derivatives of monosaccharides of D-galactose, D-glucose, D-xylose and L-rhamnose, in the analyzed saponins were identified by comparison of their retention times $(R t)$ with those of authentic samples (Sigma-Aldrich, Steinheim, Germany) treated in the same way as described above. The Rt of D-rhamnose was obtained by reaction of its $\mathrm{L}$ enantiomer with $\mathrm{D}$-cysteine methyl ester (Tanaka et al., 2007) due to the lack of an authentic sample; (Rt: D-galactose $10.10 \mathrm{~min}$, L-galactose $10.20 \mathrm{~min}$, D-glucose $10.40 \mathrm{~min}$, L-glucose $10.18 \mathrm{~min}$, D-xylose $10.69 \mathrm{~min}$, L-xylose $10.54 \mathrm{~min}$, L-rhamnose $11.54 \mathrm{~min}$, D-rhamnose $9.95 \mathrm{~min}$ ).

\subsection{Bioassay}

Etiolated wheat coleoptile assays and phytotoxicity bioassays with the monocot A. cepa L. (onion) and dicots L. esculentum Will. (tomato), L. sativum L. (cress) and L. sativa L. (lettuce) as standard target species (STS) were conducted under the conditions reported in our previous work (Pérez et al., 2013). Extracts and fractions were assayed at concentrations of 800,400 and $200 \mathrm{ppm}$ and pure compounds at $333,100,33,10,3.3,1 \mu \mathrm{M}$. Control samples (buffered aqueous solutions without any test compound) and the commercial herbicide $\operatorname{Logran}^{\circledR}$, a combination of $\mathrm{N}$-(1,1-dimethylethyl)- $N^{\prime}$-ethyl-6-(methylthio)-1,3,5-triazine-2,4-diamine (Terbutryn, 59.4\%) and 2-(2-chloroethoxy)-N-\{[(4-methoxy-6-methyl-1,3, 5-triazin-2yl)amino]carbonyl \}benzene-sulfonamide (Triasulfuron, $0.6 \%$ ), were used as internal references (Macías et al., 2000) and were tested under the same conditions as the samples.

The evaluated parameters in the phytotoxicity assay (germination rate, root length and shoot length) were recorded using a Fitomed ${ }^{\circledR}$ system (Castellano et al., 2001), which allowed automatic data acquisition and statistical analysis using its associated software. Data were analyzed statistically using Welch's test, with significance fixed at 0.01 and 0.05 . Results are presented as percentage differences from the control. Zero represents control, positive values represent stimulation, and negative values represent inhibition. The concentration that resulted in a $50 \%$ inhibition $\left(\mathrm{IC}_{50}\right.$ values) was calculated from the dose-response curve.

\section{Acknowledgements}

This research was supported by the Ministerio de Educación y Ciencia (Project No. AGL2009-08864 (AGR)), Junta de Andalucía 
(P10-AGR-5822), Seville, Spain and by the European Union's Seventh Framework Program project 'Proficiency' (FP7-REGPOT2009-1-245751). A fellowship from the Agencia Española de Cooperación Internacional para el Desarrollo, AECID (A.J.P.) is also gratefully acknowledged.

\section{Appendix A. Supplementary data}

Supplementary data associated with this article include $1 \mathrm{H}, 13 \mathrm{C}$ (UDEFT), HSQC, HMBC, ROESY, DQF-COSY, TOCSY, HSQC-TOCSY, 1D TOCSY and 1D ROESY NMR spectra, High Resolution Mass Spectra and ESI-MS/MS spectra for the new compounds (1-5). Etiolated wheat coleoptiles and phytotoxicity bioassay experimental procedures. Figure showing the effects of compounds 1-6, 9 and 11 on germination and shoot growth of Lactuca sativa. Supplementary data associated with this article can be found, in the online version, at http://dx.doi.org/10.1016/j.phytochem.2014.05.014. These data include MOL files and InChiKeys of the most important compounds described in this article.

\section{References}

Agrawal, P.K., 2004. Dependence of ${ }^{1} \mathrm{H}$ NMR chemical shifts of geminal protons of glycosyloxy methylene $\left(\mathrm{H}_{2}-26\right)$ on the orientation of the 27-methyl group of furostane-type steroidal saponins. Magn. Reson. Chem. 42, 990-993.

Agrawal, P.K., 2005. Assigning stereodiversity of the 27-Me group of furostane-type steroidal saponins via NMR chemical shifts. Steroids 70, 715-724.

Bousios, A., Saldana Oyarzabal, I., Valenzuela Zapata, A.G., Wood, C., Pearce, S.R., 2007. Isolation and characterization of Ty1-copia retrotransposon sequences in the blue agave (Agave tequilana Weber var. azul) and their development as SSAP markers for phylogenetic analysis. Plant Sci. 172, 291-298.

Castellano, D., Macías, F.A., Castellano, M., Cambronero, R., 2001. Sistema automatizado para la adquisición simultánea y gestión informatizada de medidas de longitud variable. Spanish Patent No P9901565.

Hernández Carlos, B., González Coloma, A., Orozco Valencia, A.U., Ramírez Mares, M.V., Andrés Yeves, M.F. Joseph Nathan, P. 2011. Bioactive saponins from Microsechium helleri and Sicyos bulbosus. Phytochemistry 72, 743-751.

Huang, P.L., Gan, K.H., Wu, R.R., Lin, C.N., 1997. Benzoquinones, a homoisoflavonone and other constituents from Polygonatum alte-lobatum. Phytochemistry 44 1369-1373.
Macías, F.A., Castellano, D., Molinillo, J.M.G., 2000. Search for a standard phytotoxic bioassay for allelochemicals. Selection of standard target species. J. Agric. Food Chem. 48, 2512-2521.

Macías, F.A., Guerra, J.O., Simonet, A.M., Nogueiras, C.M., 2007. Characterization of the fraction components using 1D TOCSY and 1D ROESY experiments. Four new spirostane saponins from Agave brittoniana Trel. spp. Brachypus. Magn. Reson. Chem. 45, 615-620.

Macías, F.A., Guerra, J.O., Simonet, A.M., Pérez, A.J., Nogueiras, C., 2010. Characterization of three saponins from a fraction using 1D DOSY as a solvent signal suppression tool. Agabrittonosides E-F. Furostane saponins from Agave brittoniana Trel. spp. Brachypus. Magn. Reson. Chem. 48, 350-355.

Marchaim, U., Werker, E., Thomas, W.D.E., 1974. Changes in the anatomy of cotton seed coats caused by lucerne saponins. Bot. Gaz. 135, 139-146.

Marker, R.E., Wagner, R.B., Ulshafer, P.R., Wittbecker, E.L., Goldsmith, D.P.J., Ruof, C.H., 1943. Sterols. CLVII. Sapogenins. LXM'. Isolation and structures of thirteen new steroidal sapogenins. New sources for known sapogenins. J. Am. Chem. Soc. 65, 1199-1209.

Oleszek, W., 1993. Allelopathic potential of alfalfa (Medicago sativa) saponins: their relation to antifungal and haemolytic activities. J. Chem. Ecol. 19, 1063-1074.

Oleszek, W., 2000. Alfalfa saponins: Chemistry and application. In: Bidlack, W.R. Omaye, S.T., Meskin, M.S., Topham, D.K. (Eds.), Phytochemicals as bioactive agents. Technomic Publishing Co., Inc, Lancaster, pp. 167-188.

Pérez, A.J., Calle, J.M., Simonet, A.M., Guerra, J.O., Stochmal, A., Macías, F.A., 2013. Bioactive steroidal saponins from Agave offoyana flowers. Phytochemistry 95 298-307.

Piotto, M., Bourdonneau, M., Elbayed, K, Wieruszeski, J.M. Lippens, G, 2006. New DEFT sequences for the acquisition of one-dimensional carbon NMR spectra of small unlabelled molecules. Magn. Reson. Chem. 44, 943-947.

Podolak, I., Galanty, A., Sobolewska, D., 2010. Saponins as cytotoxic agents: review. Phytochem. Rev, 9, 425-474.

Sati, O.P., Pant, G., 1985. Cantalasaponin-1, a novel spirostanol bisdesmoside from Agave cantala. J. Nat. Prod. 48, 395-399.

Scognamiglio, M., D’Abrosca, B., Fiumano, V., Chambery, A., Severino, V., Tsafantakis, N., Pacifico, S., Esposito, A., Fiorentino, A., 2012. Oleanane saponins form Bellis sylvestris Cyr. and evaluation of their phytotoxicity on Aegilops geniculata Roth. Phytochemistry 84, 125-134.

Tanaka, T., Nakashima, T., Ueda, T., Tomii, K., Kouno, I., 2007. Facile discrimination of aldose enantiomers by reversed-phase HPLC. Chem. Pharm. Bull. 55, 899-901.

Wall, M.E., Willaman, J.J., Perlstein, T., Correll, D.S., Gentry, H.S., 1957. Steroida sapogenins XXXIX. Occurrence and isolation of gentrogenin and correllogenin from Dioscorea spiculiflora. J. Pharm. Sci. 46, 155-159.

Waller, G.R., Yang, C.F., Chen, L.F., Su, C.H., Liou, R.M., Wu, S.C., Young, C.C., Lee, M.R. Lee, J.S., Chou, C.H., Kim, D., 1996. Can soyasaponin I and mono- and bidesmosides isolated from mungbeans serve as growth enhancers in mungbeans and lettuce? Adv. Exp. Med. Biol. 405, 123-139.

Xie, B.B., Liu, H.Y., Ni, W., Chen, C.X., 2009. Ypsilandrosides C-G, five new spirostanol saponins from Ypsilandra thibetica. Steroids 74, 950-955. 